\title{
Bone marrow necrosis in an adult patient with precursor B-cell acute lymphoblastic leukaemia at the time of presentation
}

\author{
Najmaddin S H Khoshnaw, ${ }^{1}$ Dana Nasraldeen Muhealdeen ${ }^{2}$
}

\begin{abstract}
'Department of Haematology, Hiwa Hospital, Sulaymaniyah, Iraq

${ }^{2}$ Department of Pathology, Shorh Hospital, Sulaymaniyah, Iraq
\end{abstract}

Correspondence to Dr Najmaddin S H Khoshnaw, najmaddin_salih@yahoo.com

Accepted 15 March 2014
CrossMark

To cite: Khoshnaw NSH Muhealdeen DN. BMJ Case Rep Published online: [please include Day Month Yearl doi:10.1136/bcr-2014203891

\section{DESCRIPTION}

A 58-year-old Kurdish woman with a history of diabetes, presented to our clinic with fever and rigour for 2 week's duration, associated with diffuse bone pain and weight loss. Laboratory work showed pancytopenia with haemoglobin $107 \mathrm{~g} / \mathrm{L}$, white cell count $3.3 \times 109 / \mathrm{L}$ (absolute neutrophil count $1.5 \times 109 / \mathrm{L})$ and platelet count $8 \times 109 / \mathrm{L}$, lactate dehydrogenase was $1227 \mathrm{U} / \mathrm{L}$ and uric acid $8 \mathrm{mg} /$ $\mathrm{dL}$. The blood film showed normochromic normocytic anaemia with rouleaux formation. A bone marrow aspiration was diluted and looked like an artefact, no megakaryocytes detected, the blasts account for $40 \%$ on the available cells, and they were of acute lymphoblastic leukaemia (FrenchAmerican-British (FAB)-L2; figure 1). The bone marrow biopsy revealed diffuse necrosis, cells loosing normal staining with coagulative necrosis of marrow elements in an amorphous eosinophilic background, with a small focus of lymphoid cells and few residual megakaryocytic cells seen (figure 2). Flow cytometry revealed positive CD19, CD10, TDT, CD34 and CD79a while negative for T-cell markers. The patient received a five-drug remission induction regimen with intensive consolidation used for the patient (Larson protocol). We gave cyclophosphamide, daunorubicin, vincristine, prednisone and L-asparagines on 21 July 2013. She got complete remission with normal bone marrow aspirate and disappearance of necrosis on day 28 of her treatment. Bone marrow necrosis (BMN) is an uncommon clinicopathological condition which is diagnosed at postmortem period. BMN is mostly caused by malignancy especially haematological as acute leukaemias, relapsed Hodgkin's lymphoma or solid tumours as gastrointestinal tract and prostate

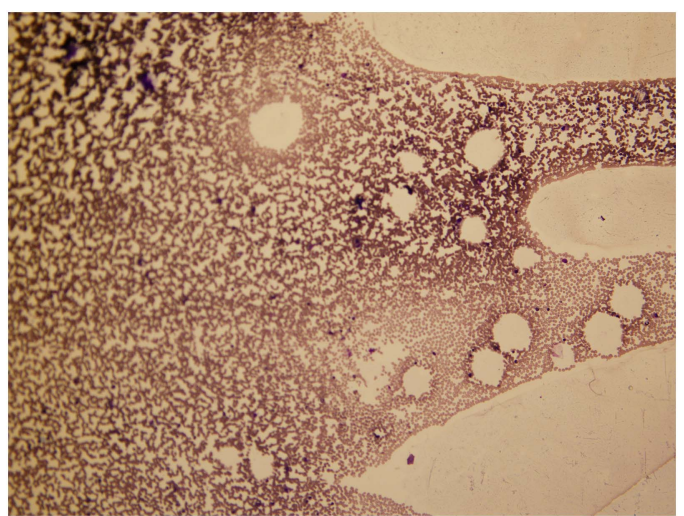

Figure 1 Bone marrow aspirate of the patient with bone marrow necrosis, showing diluted marrow which looked like an artefact (Giemsa stain).

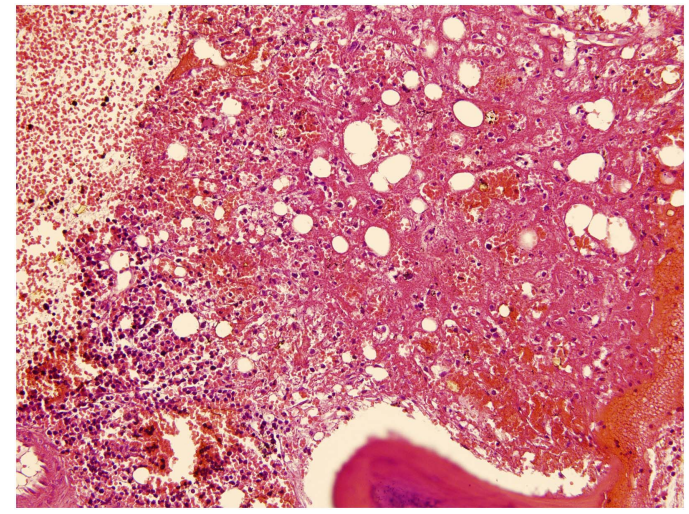

Figure 2 Bone marrow biopsy of the patient with bone marrow necrosis (H\&E stain) revealed diffuse necrosis, cells loosing normal staining with coagulative necrosis of marrow elements in an amorphous eosinophilic background, with a small focus of lymphoid cells and few residual megakaryocytic cells could be seen.

adenocarcinoma, stomach and colon cancer. Non-haematological causes as sickle cell disease, infections as tuberculosis and toxic effects of chemotherapy such as interferon $\alpha$, granulocyte colony stimulating factor (G-CSF), all trans-retinoic acid (ATRA) and fludarabine. Rare causes of BMN are anorexia nervosa, haemolytic uraemic syndrome and antiphospholipid syndrome were reported. $^{1}{ }^{2}$ Pathophysiology is unknown but could be due to marrow microvascular obstruction, cytokine release and T-cell and granulocyte activation. ${ }^{1-3}$ So by early diagnosis and good supportive treatment the prognosis is promising unlike that mentioned in the literature.

\section{Learning points}

- The diagnosis of bone marrow necrosis (BMN) may be difficult especially if presented before or at the time of disease presentation. BMN is associated with high morbidity and mortality. Early diagnosis and treatment is promising.

- In BMN there is destruction of the normal marrow architecture with necrosis of the myeloid elements with or without trabeculae bone destruction.

- The necrotic area is more obvious in bone marrow biopsy specimen, than aspirate.

- The cause may be due to marrow microvasculature obstruction by leukaemia cells.

Acknowledgements The authors thank Dr Rekawt Hama Rasheed, Ministry of Health for giving the opportunity for doing researches. They gratefully appreciated the cooperation in Shorsh Hospital especially the pathology unit. 
Contributors NSHK received the patient and collected all clinical data, diagnosed, treated and managed the case, and also wrote all parts of the article. DNM shared in preparation of biopsy sample, doing immunohistochemistry and reading and interpreting the laboratory data.

Competing interests None.

Patient consent Obtained.

Provenance and peer review Not commissioned; externally peer reviewed.

\section{REFERENCES}

1 Paydas S, Ergin M, Baslamisli F, et al. Bone marrow necrosis: clinicopathologic analysis of 20 cases and review of the literature. Am J Hematol 2002;70:300-5.

2 Foucar K. Miscellaneous disorders of bone marrow including stromal and bone marrow abnormalities. In: Bone marrow pathology 2. Chicago: ASCP Press, 2001:546-85.

3 Eusni RM, Hamidah HN, Zarina AL, et al. Bone marrow necrosis preceding infantile acute lymphoblastic leukemia. Malays J Pathol 2007;29:113-17.

Copyright 2014 BMJ Publishing Group. All rights reserved. For permission to reuse any of this content visit http://group.bmj.com/group/rights-licensing/permissions.

BMJ Case Report Fellows may re-use this article for personal use and teaching without any further permission.

Become a Fellow of BMJ Case Reports today and you can:

- Submit as many cases as you like

- Enjoy fast sympathetic peer review and rapid publication of accepted articles

- Access all the published articles

- Re-use any of the published material for personal use and teaching without further permission

For information on Institutional Fellowships contact consortiasales@bmjgroup.com

Visit casereports.bmj.com for more articles like this and to become a Fellow 